\title{
Snowy Owls and Gray Partridge near Saskatoon in the Winter of 1963-1964
}

\author{
by J. B. Gollop, Saskatoon
}

Every fall Snowy Owls (Nyctea scandiaca) move south into Saskatchewan. Among the more conspicuous animals that might serve as food for them are Gray or Hungarian Partridge (Perdix perdix). In the course of weekend and holiday driving last winter, my wife and I recorded all individuals of these and most other animals seen. This note presents some results of these casual observations and suggests how winter bird distribution might be more systematically investigated.

All observations were made within a 40-mile radius of Saskatoon. Most of the land in this district is used for raising wheat and barley but there is some grazing land. Trees and bushes occur in and around depressions and along rivers and creeks; more extensive stands are found in the northwest quarter of the area. Topography varies from gently undulating to moderately rolling and altitudes are from 1,500 to 2,200 feet above sea level.

We drove a total of 3,700 miles in the country from November, 1963, through April, 1964. Most observations were made from a car going 20 to 35 miles per hour and practically all driving was done between 12 and 5 p.m., C.S.T. Monthly mileages (corrected for odometer error) were as follows: November, 420 miles (on eight days); December, 715 miles (13 days); January, 550 miles (10); February, 675 miles (11); March, 760 miles (9); April, 610 miles (11). Some routes were duplicated but no attempt was made to drive the same routes at regular intervals. Often when a stop was made to record data, the landscape was scanned with $7 \times 50$ binoculars (or $30 \times 60$ spotting scope). As a result, an area with more birds near the road tended to have more birds recorded away from the road. No record was kept of Snowshoe Rabbits or Hares (Lepus americanus), farm dogs, or mammal tracks, the latter probably being a better indication of distribution than direct observations of the animals themselves.

Many factors affect counts made from a road. We had little information on how daily and seasonal activities of the birds might affect their visiblity. Since Snowy Owls occupy higher sites -knolls, posts, poles, etc.-than partridge, we probably saw a higher and more consistent proportion of owls. Most partridge were observed on or near the road, often largely hidden in the snow; when flushed they usually flew into bushes, trees, farm yards and over hills out of sight. Traffic, predators and lack of solid snow cover, as was the case in December and March, probably adversely affected counts of partridge more than owls. On the other hand, owls are less easily seen on overcast days than in bright sunshine; while cloud conditions probably have less effect on partridge counts. We do not know the effect of other weather factors, e.g., temperature and wind, on the habits of other species. Distance of birds from the road was not recorded on a regular basis, but the figures below may include most of the partridge within one-eighth mile of the road and most owls within a half mile, if not a full mile, of it.

From November 3, 1963, to March $30,1964,154$ Snowy Owls were recorded. We do not know whether this is a high, medium or low number of owls for this district. Their monthly distribution and the average number of linear miles driven for one owl observation were as follows: November: 1 owl (1 owl:420 miles); December: 23 (1:31); January: 58 (1:9); February: 26 (1:26); March: 46 (1:17); April: none in 610 miles. A total of 2,145 partridge were recorded: 61 in November, 290 in December, 493 in January, 1,077 in February, 210 in March, 14 in April. We saw no evidence of shooting but did find six dead partridge, one dead Sharp-tailed Grouse (Pedioecetes phasianellus) and three dead owls near the road.

Generally speaking, Gray Partridge and Snowy Owls did not appear to concentrate in the same areas. Table 1 shows the geographical relationship between concentrations of these species as well as related numbers of Sharp-tailed Grouse, eagles (Aquila 


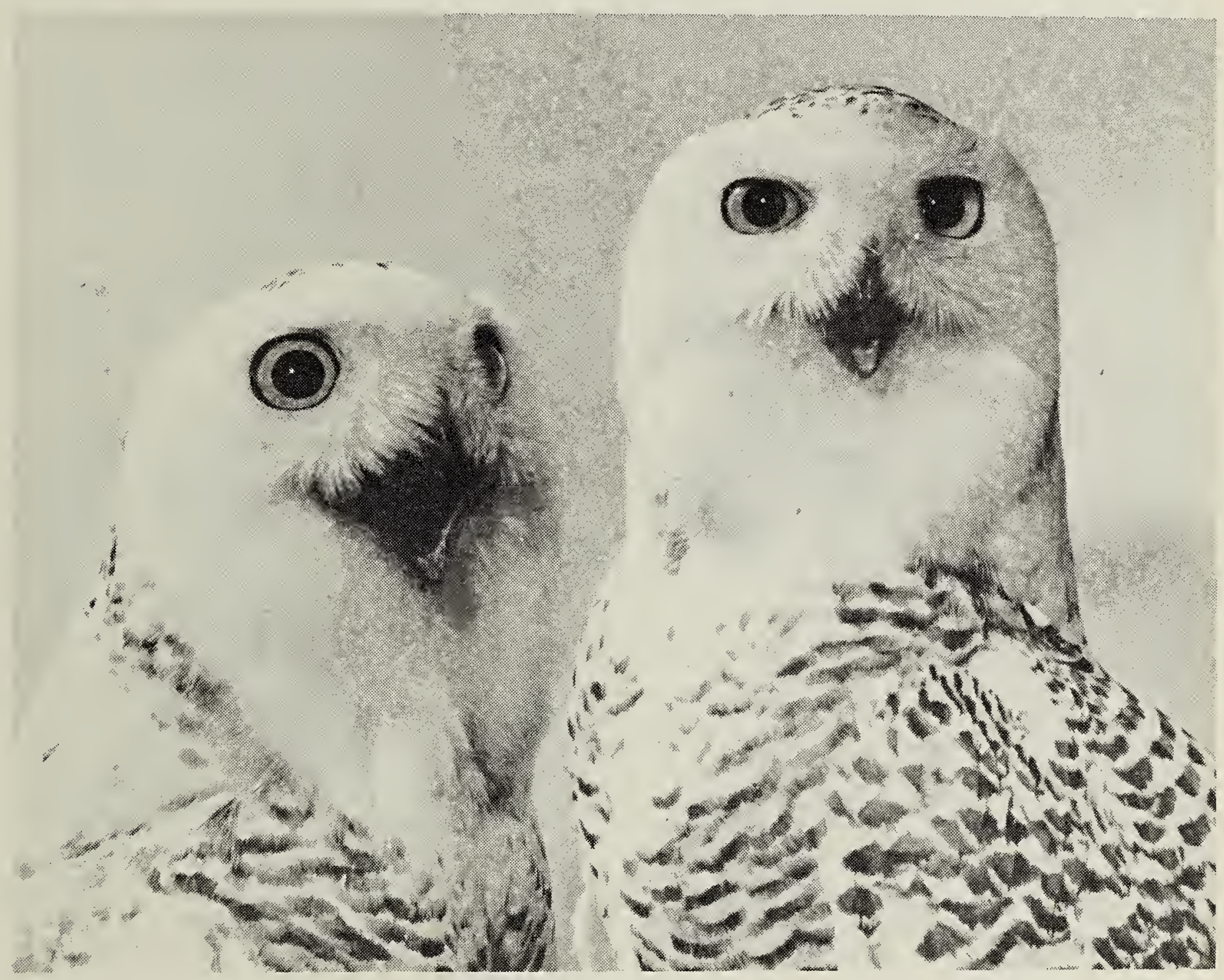

Snowy Owls

Studio portrait by R. R. Taylor

chrysaetos in one case), Goshawks (Accipiter gentilis), Short-eared Owls (Asio flammeus), Red Foxes (Vulpes fulva) and Coyotes (Canis latrans). A concentration is here defined as an average of two or more partridge per mile or one Snowy Owl in two miles or less of a given route. (Numbers in parentheses are dead birds, not included in totals.)

In only three instances (January 19 , February 23 and 29) of 12 did large numbers of owls and partridges occur in the same area. On the other hand, other predators, particularly eagles and foxes, which were probably much less abundant than Snowy Owls, were recorded only in districts with partridge concentrations.

Based on other observations (Table 2 ), it would appear that the three high partridge-owl concentrations were fortuitous or temporary. Because of blocked roads and lack of a carefully 
planned project only a few areas received identical coverage several times during the season. Three such areas are shown in Table 2.

In the Vanscoy-Delisle-Asquith area it will be noted that at least 11 owls moved through the area between January 1 and February 2, in spite of a continuing, high population of partridge. (This assumes that the owls did not die or were not overlooked on February 2.) On March 28 in the AllanElstow-Clavet district, 17 owls were noted in an area that had practically no partridge or owls on three previous trips. South of Clavet, six owls were present on February 29 with a concentration of partridge. The absence of partridge on March 30 could be attributed to flock dispersal due to pairing. Partridge were observed courting near Saskatoon on March 2.

No predators were seen to attack partridge. On December 23 a Snowy Owl was seen chasing a Rock Dove (Columba livia) which it did not catch; on February 23 an owl flew from a ditch with some unidentified prey.

As stated above, we have little information on actual densities of birds. The highest density of owls was noted on the last date that any were seenMarch 30. Seven birds were observed in $1.5 \mathrm{sq}$. mi. of cultivated land within two miles of Allan. The highest density of partridge was 70 in one-quarter sq. mi. around two deserted farms, four miles northwest of Delisle on Feb. 2. A fox and a Snowy Owl were seen together about two miles from this concentration. While densities are not indicated, a 26 -mile stretch of road between Hanley and Allan had an unusual variety of predators through the winter. On December 8 an eagle was seen. On December 28 there were four Short-eared and three Snowy Owls, one fox, and a Coyote had treed a Lynx (Lynx canadensis). On March 30 two Great Horned Owls (Bubo virginianus) were flushed from a nest along this route and a northbound Marsh Hawk (Circus cyaneus) was noted. Other spècies on December 28 were partridge (42), pheasants (2), Rock Doves, Horned Larks (Eremophila alpestris, 2), magpies (Pica pica, 7), House Sparrows (Passer domesticus), redpolls (Acanthis flammea, 275), and Snow Buntings (Plectrophenax nivalis, 105).

In spite of biases of unknown quantity and magnitude, the above data indicate that Snowy Owls in the Saskatoon district during the winter of 1963-64 did not concentrate in areas of high partridge populations. This in turn may indicate that Gray Partridge were not an important source of food for many Snowy Owls. On the other hand it appears that eagles and foxes were more closely associated with concentrations of partridge.

Populations of Snowy Owls in Saskatchewan apparently fluctuate from one winter to the next but there is no quantitative information on their numbers. Statements on abundance are usually based on impressions or reports from taxidermists. It may be that a network of roadside counts through the southern part of the province, conducted annually and in such a manner as to avoid the defects pointed out above, could provide an

Table 1. Geographical relationship between partridge and possible predators.

\begin{tabular}{|c|c|c|c|c|c|c|c|c|c|}
\hline \multirow{3}{*}{ Jan. } & \multirow{3}{*}{$\begin{array}{l}1 \\
1\end{array}$} & \multirow{3}{*}{$\begin{array}{l}\text { Area } \\
\text { Vanscoy-Delisle-Asquith } \\
\text { Vanscoy-Delisle-Asquith }\end{array}$} & \multirow{2}{*}{\multicolumn{2}{|c|}{ Miles }} & \multicolumn{5}{|c|}{$\begin{array}{l}\text { Gray } \\
\text { Port- S-t. Snowy Other } \\
\text { ridge Grouse Owls Predators }\end{array}$} \\
\hline & & & & & 143 & 5 & 1 & 1 & Golden Eagle \\
\hline & & & next & -10 & 0 & 0 & 5 & 0 & \\
\hline$" \prime$ & 5 & Aberdeen-Vonda & & 27 & 0 & 0 & 15 & 0 & - \\
\hline " & 19 & Vanscoy-Delisle-Asquith & & 20 & 47 (1) & 0 & 12 & 2 & eagles \\
\hline$"$ & 26 & Clavet-Elstow & & 39 & 192 & 0 & 2 & 1 & fox, 2 SEO* \\
\hline Feb. & 2 & Vanscoy-Delisle-Asquith & & 40 & 171 & 1 & 2 & 1 & fox, 1 eagle \\
\hline$" \prime$ & 15 & Vanscoy-Delisle-Asquith & & 45 & $227(1)$ & 0 & 2 & 1 & Coyote, I Goshawk \\
\hline “ & 16 & Saskatoon-Bradwell & & 56 & 138 & $2^{* *}$ & 2 & 2 & foxes, I SEO* \\
\hline$" \prime$ & 23 & Floral-Dundurn-Elstow & & 75 & 154 & 2 & 5 & 2 & foxes \\
\hline$" 1$ & 29 & South of Clavet & - & 7 & 33 & 0 & 6 & 1 & eagle \\
\hline Mar. & 1 & Saskatoon-Delisle-Asquith & $-\cdots$ & 39 & 96 & $8(1)$ & ) 1 & 0 & \\
\hline$" \prime$ & 30 & Allan-Elstow & & 20 & 0 & 0 & 19 & 0 & \\
\hline
\end{tabular}

*Short-eared Owl. **Also l Ring-necked Pheasant (Phasianus colchicus) 
Table 2. Partridge and possible predator relationships in three areas that were closely examined during the season.

\begin{tabular}{|c|c|c|c|c|}
\hline & & \begin{tabular}{|l|} 
Gray \\
Partridge \\
\end{tabular} & $\begin{array}{c}\text { Snowy } \\
\text { Owls }\end{array}$ & Others \\
\hline Vanscoy-Delisle-Asquith & Jan. 1 & 105 & 1 & 1 Golden Eagle \\
\hline \multirow[t]{4}{*}{20 miles } & " 19 & 47 & 1.2 & 2 eagles \\
\hline & Fèb. 2 & 149 & 1 & 1 eagle, 1 fox \\
\hline & " 15 & 162 & 2 & 1 Goshawk \\
\hline & Mar. 1 & 60 & 1 & - \\
\hline \multirow{4}{*}{$\begin{array}{l}\text { Allan-Elstow-Clavet: } \\
18 \text { miles }\end{array}$} & Dec. 28 & 8 & 1 & - \\
\hline & Jan. 26 & 0 & 0 & 一 \\
\hline & Feb. 23 & 6 & 0 & 一 \\
\hline & Mar. 30 & 0 & 17 & 一 \\
\hline \multirow{4}{*}{$\begin{array}{l}\text { South of Clavet: } \\
7 \text { miles }\end{array}$} & Jan. 26 & 48 & 1 & - \\
\hline & Feb. 16 & 24 & 2 & 1 fox \\
\hline & Feb. 29 & 33 & 6 & 1 eagle \\
\hline & Mar. 30 & 2 & 0 & 1 Golden Eogle \\
\hline
\end{tabular}

index of abundance from year to year. The requirements might be: (1) A route of at least 40 miles (based on miles-per-owl above) along a road likely to be kept open during the winter. A route that starts and ends near home is ideal. (2) Coverage every two to four weeks from November through April. Routes should be covered during the same part of the day each time and, if possible, under clear skies. (3) Observations made in a consistent manner, e.g., a $360^{\circ}$ scanning of the landscape with binoculars at two-mile intervals and naked-eye observations in between while driving 20 30 m.p.h. The same, preferably two, observers should conduct the survey each time. Record should also be kept of snow conditions.

Such an undertaking might also yield information on the status of upland game birds and other species. As indicated above, it can give a birdwatcher a new perspective of what is usually considered a slack season for birds.

\title{
Twenty-third Annual Saskatchewan Christmas Bird Count, 1964
}

\author{
compiled by Mary Houston, Saskatoon
}

Unfavorable weather during the entire Christmas season seems to have discouraged bird counters this year. Reports were received from only 25 Saskatchewan points (two of these count areas reporting from Kelvington) and only 48 species of birds were seen on count day with an additional seven species during the count period. A Trumpeter Swan at Regina, the only species not seen previously on a Saskatchewan Christmas bird count, brings the 23-year total to 111 species.

Black-billed Magpies, seen in all 25 localities and House Sparrows reported from 23, were the commonest birds, with Black-capped Chickadees running a close third in 19 of the 25 possible localities. Sharp-tailed Grouse were reported in 17 and Gray Partridge in 16 of the counts. Of particular interest was the Horned Lark, seen in 13 localities, many of them further north than is to be expected at this time, especially in a year with below average temperatures and above average snowfall.

Regina led the field with 37 species, including quite a variety of waterfowl. Saskatoon's claim to fame was perhaps endurance-the temperature being $-35^{\circ}$ at 9 a.m. and still $-34^{\circ}$ at noon.

One count each was received from Alberta and the Northwest Territories. 